\title{
School and Bachelor Students in the Digital Landscape: Securing Continuity
}

\author{
Irina A. Stikhina* \\ Ural State University of Economics, Ekaterinburg, Russian Federation \\ ${ }^{*}$ Corresponding author. Email: aniris.irina@yandex.ru
}

\begin{abstract}
The article considers the problematic area of distance education at different educational levels. The continuity as a relevant condition for successful individual educational route is one of the factors that should be analysed while discussing education for sustainability. Providing the continuity between different educational levels in the digital landscape is a challenge that should be overcome in order to structure and direct students' learning process through all the stages. The author analyses data, obtained within a conducted survey, and suggests some recommendations for developing educational programs with digital components providing the necessary continuity between schools and universities.
\end{abstract}

Keywords: sustainable education, continuity, distance learning, blended format, online course.

\section{INTRODUCTION}

The modern world is characterized by profound changes that affect all of humanity. These are processes and problems related to various aspects of human life globalization, demography, infectious threats, digitalization, climate change. All of them lead to transformations in society, state, politics, medicine, economy, and, of course, education. As educational institutions are responsible for the future of new generations, they must provide modern education that ensures professional, social, environmental and digital competencies required in a globalized world.

Political, economic, demographic and other changes are constantly transforming the educational environment. Nowadays, due to the COVID-19 pandemic, these transformations have rapid speed. In this regard, discussions about sustainable education in an era of uncertainty are experiencing a boom. There are various works that describe what conditions must be ensured for the sustainability of educational systems. Within the framework of these studies, the institutional structure, learning process, research practice, required reporting, and many other factors are analysed [1]. Education for sustainable development (EfS) is studied at different academic levels. Researchers analyse EfS in course curricula, investigate projects involving EfS as well as try to adopt different theoretical approaches [2].
Digitalization or digital transformation - namely, automation, the possibility of using artificial intelligence systems made possible the emergence of a new learning format, which became both a significant challenge and an opportunity for education. One of the problems is that digital format requests completely new materials. Designing online courses is a complicated process. The development phase requires the involvement of many stakeholders (e.g. educators, IT professionals, administrative staff etc.). The responsibility of teachers is also changing, say M. Shopuisen and M. Kalz. Participants in their survey indicate that some educators may feel reluctant to play new roles and take on new tasks when developing online courses [3].

The researchers state that there are several reasons for the reluctance of university teachers "to utilize the wide spectrum of possibilities embedded in online teaching: (1) Unbundling of the professional responsibility; (2) Work overload and burnout; (3) Lack of ongoing support systems; and (4) Intellectual property concerns" [4]. All these reasons are serious enough to hinder the smooth transition to digital format.

Another problem is that one of the main results of the digitalization in education is total individualization. On the one side, an individual approach to a student has a positive effect on the quality of education. On the other side, "dialogue through a computer" significantly reduces the speech activity which objectivates human 
thinking. In such a situation, the practice of formulating thoughts in a professional language is minimal. Therefore, difficulties can arise when an alumnus starts a professional career.

The problems mentioned above are on the surface, however, while researching the problematic area, other difficulties arise. Nowadays, it is highly relevant to identify the main characteristics of distance education in the current period and outline the prospects for its development at schools and universities. As schools are involved in the digital landscape at the basic stage of education, they set frames, methods and regulations for this format. With the digital skills gained at school, students continue their education at other stages, and the experience they have made there influences their individual educational routes. Therefore, the continuity between school and university is an important factor, which cannot be underestimated.

The problem of continuity in education is the issue that has been investigated for many decades. A. P. Smanzer stated in 1992 that the purpose of his research was the development of a didactic concept of continuity in teaching schoolchildren and students. His hypothesis was that the implementation of continuity will ensure a progressive, continuous pedagogical process in secondary and higher education, if, among others, close interaction of the leading components within the learning process in secondary and higher education (content, teaching methods and components of educational and cognitive activities of schoolchildren and students) is carried out. Conformity and consistent logical change of organizational forms and methods of school and university education has also to be ensured [5]. Later, in 2011, E. N. Ovcharenko says that changing goals and approaches in education requires improving the continuity between secondary and higher institutions, looking for new ways and exploring the possibilities of using innovative didactics and computer technologies to implement the principle of continuity. The researcher emphasizes that the national doctrine of education for the period up to 2025 is focused on new conditions for the functioning of education in accordance with the current socio-economic situation in the country. Today, a university graduate must not only have a high level of professionalism and be a comprehensively developed personality, but also have professional mobility, readiness for professional growth and acquiring new knowledge throughout his life. The personality-oriented teaching paradigm is focused not only on the transfer of a fixed amount of knowledge to students, but also on the formation of the ability to learn and the development of interest in the cognitive process [6]. Digitalization should facilitate the achievement of these goals. Exploring and researching in the field of continuity has never been as relevant as nowadays, since computer technologies are an integral part of all learning processes, and distance education may not only simplify learning but also cause different challenges.

The purpose of the study is to suggest appropriate ways of developing the continuity in the digital landscape between two educational stages - schools and universities. To achieve this purpose, it is required to complete the following tasks: 1) to study the features of distance education and identify the options for using digital technologies; 2) define students' focus groups to conduct a survey in order to find out their attitude to distance education; 4) design a questionnaire for the survey; 5) analyse data obtained within the survey; 6) highlight the problems of distance and offline learning formats as well as the preferences of students; 7) outline possible prospects and recommendations for the use of distance technologies in school and university education to ensure the continuity between these educational levels.

\section{MATERIALS AND METHODS}

The methods used are the methods of content analysis, polling, as well as deductive, inductive and comparative methods. The practical application of the study is possible when drawing up educational programs with distant components both for school and university courses.

The first task is to define the main features of distance learning. In general, it is a type of training based on educational interaction between teachers and students distant from each other, using telecommunication technologies that ensure the delivery of the studied material to the students as well as interaction between students and teachers in the learning process. Distance learning is characterized by all the components inherent in the educational process: meaning, goals, content, organizational forms, training tools, a system for monitoring and evaluating results. Currently, this format of education is relevant, especially due to the pandemic. The purpose of distance learning is to provide students directly at the place of their residence or temporary stay with the opportunity to master educational programs at institutions of secondary and higher education. Some advantages and disadvantages of distance and traditional face-to-face learning are presented in the table below.

Of course, this list can be modified. Based on pros and cons, it can be stated that distance learning has a large number of negative sides. However, there are many technologies that make it as convenient and close to traditional education as possible, for example, the increasingly popular wireless communication services for organizing video conferencing, webinars and group chats like Zoom, Teams and others, which allow communication via video and audio as well as the use of chat and shared screens. Installed on a computer, tablet or smartphone, such applications are perfect for distance lectures. In addition, there are platforms that allow 
Table 1. Advantages and disadvantages of distance and traditional face-to-face learning.

\begin{tabular}{|c|c|c|}
\hline & Pros & Cons \\
\hline \multirow[t]{4}{*}{$\begin{array}{l}\text { Distance } \\
\text { Learning }\end{array}$} & $\begin{array}{l}\text { Safety. The fear to get sick and infect others is much } \\
\text { lower, which is especially important in a pandemic. }\end{array}$ & $\begin{array}{l}\text { Lack of socialization, which is important } \\
\text { enough for most adolescents. }\end{array}$ \\
\hline & $\begin{array}{l}\text { Most computer technologies are quite easy to use, which } \\
\text { greatly facilitates the educational process. }\end{array}$ & $\begin{array}{c}\text { It is more difficult to assimilate the material, } \\
\text { because during video conferences it is much } \\
\text { easier to shirk and cheat than during offline } \\
\text { class. }\end{array}$ \\
\hline & $\begin{array}{l}\text { Comfort. Nowadays, many students prefer to stay at home: } \\
\text { it makes possible to wake up later; there is no need to wear } \\
\text { school uniforms, heavy textbooks etc. }\end{array}$ & $\begin{array}{l}\text { It is more difficult for teachers to get in touch } \\
\text { with trainees, to explain educational material } \\
\text { and check its assimilation. }\end{array}$ \\
\hline & $\begin{array}{l}\text { Ability to organize your time independently, great } \\
\text { freedom of action. }\end{array}$ & \\
\hline \multirow[t]{4}{*}{$\begin{array}{l}\text { Face-to-face } \\
\text { Learning }\end{array}$} & $\begin{array}{l}\text { Pupils master the material better, because, unlike } \\
\text { videoconference, there is no possibility to turn off the } \\
\text { camera and sound during the lesson. }\end{array}$ & $\begin{array}{l}\text { Unsafe: students can become sick and infect } \\
\text { others, which is a serious problem in a } \\
\text { pandemic. }\end{array}$ \\
\hline & Socialization (development of communication skills). & $\begin{array}{l}\text { Less flexibility for students (time, pace and } \\
\text { other factors). }\end{array}$ \\
\hline & $\begin{array}{l}\text { Pupils are more willing to make contact with the teacher; } \\
\text { it is easier to maintain a conversation. }\end{array}$ & \\
\hline & $\begin{array}{l}\text { It is easier for a teacher to convey information to students } \\
\text { and check their knowledge, since during traditional classes } \\
\text { it is much more difficult to deceive the teacher and cheat. }\end{array}$ & \\
\hline
\end{tabular}

teachers to give assignments remotely, conduct independent and test work. In Russia, plenty of digital educational platforms for schools exist (e.g. "Foxford", "Reshu EGE/ Reshu OGE" (in English: "I will solve the USE and I will solve the BSE"), "YaClass" (IClass). These platforms have different ratings. They can help students prepare for exams and teachers in testing students' knowledge. Universities usually design their own platforms, where different materials and assignments can be placed, studied and checked. Besides, universities use other platforms such as Moodle etc. The diversity in the field of digital tools is huge, and, on the one hand, it is good - students can experience different electronic resources, but, on the other hand, it can confuse students and make the learning process too complicated.

Our next task was to define focus groups for the survey. It was done in 2021, in the winter term. Schoolchildren of grades 8-10 and students of the first and the fourth years of the university were identified as focus groups. This choice was based on the following assumptions: 1) teenagers of grades $8-10$ have already experienced distance learning due to the pandemic. They can critically estimate its consequences and analyse pros and cons based on their own practice; 2) first year students had some experience of distance learning at school, mainly due to the pandemic, as well as at the university. Therefore, they can draw some conclusions and share their attitudes towards it; 3) fourth year students hardly ever had any experience of distance learning at school. They experienced this format at the university in their last year of study. In general, 60 students took part in the survey: 30 pupils from Gymnasium No. 70 and 30 students of the Ural University of Economics (Ekaterinburg).

The questionnaire is designed in accordance to the purpose of the survey - to collect students' opinions about distance learning, its advantages, disadvantages and future prospects. It is supposed that students' answers will be used as relevant data for further analysing and determining the most suitable distance learning format for different levels of education - at schools and universities. We suggest that students answering the questionnaire should consider different formats of learning such as 1) traditional education; 2) distance learning with electronic resources but without videoconferencing; 3) distance education with simultaneous videoconferences, when teachers can explain the material personally and check its assimilation by students; 4) online course with specially compiled tasks based on an electronic platform.

A similar survey questionnaire was at first introduced to Master students' groups. The task was to determine the attitude of Master students towards learning in the digital landscape in order to give an overview of possible future development for Master's education programs with the focus on digitization [7]. The results of the survey conducted among the first and fourth year students of the Ural State Economic University were also presented in the conference paper "Educational Strategy in Digital Environment" [8].

The model of a questionnaire for the survey included two questions about students' preferences: 
1) Would you like to study online during the Coronavirus pandemic, or you prefer traditional classroom learning with all the necessary restrictions (distancing, disinfection, etc.)? The options for the answers are: a) traditional learning on campus; b) distance learning without virtual classrooms (using provided electronic resources: uploading and downloading materials, forums, sending messages, doing online tests etc.); c) distance learning in virtual classrooms using appropriate digital platforms and different electronic resources; d) blended learning partly online (lectures, tests etc.), partly on the territory of an educational institution (seminars, workshops, consultations etc.). Students should give their reasons for choosing an option.

The second question concerns only the digital format: 2) If you are studying in a digital environment, what would you prefer: a) classical learning in online format (the same lectures in video format and classes in virtual classrooms) or b) specially designed online courses with integrated videos, tasks etc. that would allow you to complete interactive exercises online with further evaluating by teachers (e. g. in the virtual learning environment Moodle). Again, the reasons should be given $[7,8]$.

\section{RESULTS AND DISCUSSION}

\subsection{Analysis of the Data Obtained during the Survey}

\subsubsection{Schoolchildren}

The following data were obtained from students in grades 8-11. In response to the question: "Would you like to study online during the Coronavirus pandemic, or you would prefer traditional classroom learning with all the necessary restrictions (distance, disinfection, etc.)?" the majority of schoolchildren (44\%) chose the option of blended learning, a slightly smaller number of students (28\%) preferred distance learning in virtual classrooms, some $(17 \%)$ voted for traditional education on school grounds and a minority $(11 \%)$ chose distance learning without virtual classrooms.

When asked about their preferences for learning in a digital environment, the majority of schoolchildren $(50 \%)$ indicated that they would prefer classic education online, the rest $(40 \%)$ chose specially designed online courses with integrated materials, and $10 \%$ of schoolchildren chose the option "Others".

Analysis of the data allows us to conclude that the blended learning option dominates. Distance learning in virtual classrooms is preferred to traditional learning and distance asynchronous learning. The format of distance learning in virtual classrooms is already familiar to students; perhaps this is why this option was chosen.
However, the dominance of the blended learning format proves that live communication is necessary for teenagers and distance education can not completely replace the traditional face-to-face format.

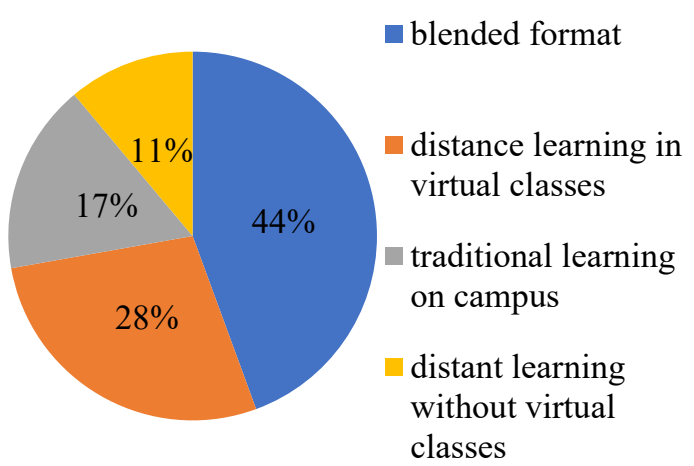

Figure 1 Schoolchildren's preferences of educational format.

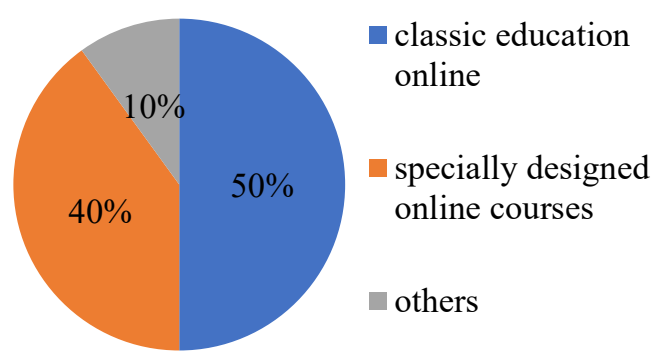

Figure 2 Schoolchildren's attitude towards distance learning.

Considering only the distance format in the second question, a large number of students chose the familiar format of learning in virtual classes, however, the percentage of children interested in specially designed online courses with integrated materials is also quite high.

\subsubsection{Students}

In the table below the data for the first and fourth year undergraduate students are presented.

The survey shows that the students of all ages prefer the option d) - "blended learning". Explaining the reasons, the most students emphasize the need to conduct practical classes offline, since this gives the opportunity for feedback, allows you to communicate with classmates and teachers, and also contributes to a better assimilation of the material, especially in some subjects (Higher Mathematics was named). However, lectures in online format are perceived as more convenient due to the possibility to download them anytime. The danger of infecting was mentioned too. In this regard, blended format is preferred since it enables everyone to reduce the risk. 
Table 2. First and fourth year students' preferences of educational format.

\begin{tabular}{|c|c|c|}
\hline Format & $\begin{array}{c}\text { First year } \\
\text { students }\end{array}$ & $\begin{array}{c}\text { Fourth year } \\
\text { students }\end{array}$ \\
\hline Blended learning & $64 \%$ & $40 \%$ \\
\hline Traditional learning on-campus & $18 \%$ & $20 \%$ \\
\hline Distance learning in virtual classrooms & $18 \%$ & $40 \%$ \\
\hline Distance learning without virtual classrooms & - & - \\
\hline $\begin{array}{c}\text { Specially designed courses with integrated materials that allow them to perform } \\
\text { interactive exercises online }\end{array}$ & $72 \%$ & $60 \%$ \\
\hline $\begin{array}{c}\text { Classic education online (the same lectures in video format and classes in virtual } \\
\text { classrooms). }\end{array}$ & $28 \%$ & $40 \%$ \\
\hline
\end{tabular}

Within digital format of study, $72 \%$ of students prefer "specially designed online courses with integrated materials that allow them to perform interactive exercises online". $28 \%$ choose classic education in online edition (the same classes but in a format of videoconferences). They note that synchronous learning, which is possible within virtual classrooms, can provide enough communication to get all necessary answers to the questions.

It can be stated that online courses are perceived positively but not all students have clear understanding of studying an online course - some students choose this option without giving any reasons; the others suppose that it is more exciting to study without writing anything down. We believe that a kind of idealization of this format is caused by the lack of sufficient training experience in the framework of such courses.

The $1^{\text {th }}$ year as well as the $4^{\text {th }}$ year students do not choose "Distance learning without virtual classrooms". It is obvious that this format is considered as the least convenient one. $20 \%$ of the $4^{\text {th }}$ year students prefer the option "traditional learning on campus". The reason they give reveals the problem of the tuition fee. $20 \%$ of students consider distance learning as less effective in comparison to traditional one and believe that recalculation is necessary. According to them, they will always prefer traditional face-to-face format of education if there is no reducing of the fee. Some students also emphasize the convenience of traditional format. On the other hand, the danger of infecting makes $40 \%$ of students choose "Distance learning in virtual classrooms". The same percentage prefers "Blended learning".

$60 \%$ of the $4^{\text {th }}$ year students choose b) -“specially designed online courses"; the rest opts for a) - "classic education online". Again, online courses are perceived ambiguously. Some students suppose that this format is an addition to virtual classes; the others talk about simplifying, better assimilation of materials, their interest in this format, and even increasing interaction between teachers and students. $40 \%$ choose a) - "classic education online". Apart the convenience of this format, they are afraid of difficulties which can arise due to the lack of special skills which they consider as necessary to master an online course.

\section{CONCLUSION}

The conducted survey shows that different generations of students have some similar points of view. Thus, schoolchildren and first-year students prefer a blended learning format. It proves that technologies cannot fully displace obtaining knowledge and communicating relevant information face-to-face, without any screens. The students are aware of the fact that face-to-face practical training facilitates intense learning process: gives them a chance to interpret different meanings and get feedback quickly.

It transpired that face-to face interaction with tutors is especially important for the fourth year students (20\%). We can assume that students do not want to change anything in the year of their graduation. Possibly, they are afraid of missing something relevant due to the distance format.

Distance learning without virtual classes (asynchronous learning) was chosen by the smallest number of schoolchildren in a focus group and by none of the students. It is obvious that this format is considered as the most ineffective one.

Specially designed online courses were elected by the most university students. The survey confirms that this format is still regarded ambiguously. The lack of practising can be the reason. However, it is necessary to note the high interest of students. They also consider this format as the more effective one. In addition, a large number of schoolchildren are also excited about it. We can assume that digital courses with integrated materials will definitely develop and take an increasing place in educational programs, especially in a situation when learning modules should be provided for designing students' individual learning trajectories. Our research has shown that students look forward to developing of distance education in this direction.

In general, the above results confirm that the digitalization of the learning process is perceived by different generations of students as a positive and significant action in education. The same attitude is 
reflected in other studies, e.g. the research "A Snapshot of University Students' Perceptions About Online Learning During the Covid-19 Pandemic" demonstrates "a positive overall attitude of University students about online distance education, with relatively high levels of perceived ease of use, perceived usefulness, perceived interest and digital competences increase $<\ldots>$ " [9].

At the same time, traditional education with a face-toface format of communication is still important for schoolchildren and university students. Thus, our recommendation is the following strategy: the emphasis should be placed on the blended format, which includes compulsory face-to-face practical classes (for example, workshops, lab based classes etc.) and distance components introduced through virtual lectures as well as different online courses with interactive tasks, preferably created on the same digital platform at least within one educational institution to minimize students' confusion while using electronic tools. Implementing this strategy at both schools and universities will allow educational institutions to ensure the continuity of learning process in the digital landscape between these educational levels. Of course, the content of learning materials, difficulties and challenges differ depending on the level, but the framework of learning in the digital landscape provided at school can structure and direct the learning process and therefore significantly improve the quality of education at all levels.

\section{REFERENCES}

[1] S. Fissi, A. Romolini, E. Gori, M. Contri, The path to an environmentally friendly university: the example of the journal Cleaner Production of the University of Florence. DOI: https://doi.org/10.101 6/j.jclepro.2020.123655.

[2] L. F. Nascimento, Special issue on education for sustainable development. Braz. J. Sci. Technol., 3 (14) (2016). DOI: https://doi.org/10.1186/s40552016-0025-4.

[3] M. Shopuiseni, M. Kalz, Educational Innovation Projects in Dutch Higher Education: Bottom Up Contextual Copying for Organizational Problems. International Journal of Educational Technologies in Higher Education, 17(36) (2020). DOI: https://doi.org/10.1186/s41239-020-00197-z.

[4] S. Guri-Rosenblit, E-teaching in higher education: An essential prerequisite for e-learning. Journal of New Approaches in Educational Research, 7(2) (2018) pp. 93- 97. DOI: https://doi.org/10.7821/nae r.2018.7.298.

[5] A. P. Smantser, Theory and practice of implementation of continuity in teaching schoolchildren and students: author's abstract of dissertation, 1992, p. 32.
[6] E. N. Ovcharenko, Continuity of education in the system of secondary and higher education based on innovative didactic technologies: abstract of dissertation, 2011, p. 25.

[7] I. A. Stikhina, Master's programmes in digital landscape. In: Proceedings of the 2nd International Scientific and Practical Conference on Digital Economy (ISCDE 2020). Series: Advances in Economics, Business and Management Research. DOI: https://doi.org/10.2991/aebmr.k.201205.005.

[8] I. A. Stikhina, Educational strategy in digital environment. In: E3S Web Conf., 2021, p. 296 08030. DOI: https://doi.org/10.1051/e3sconf/20212 9608030.

[9] T. Szopiński, K. Bachnik, Student evaluation of online learning during the COVID-19 pandemic. Technological Forecasting and Social Change, 174 (2022) p. 121203. DOI: https://doi.org/10.1016/j.te chfore.2021.121203. 